\title{
Superkondensatory hybrydowe dla komunikacji miejskiej
}

\begin{abstract}
$W$ artykule przedstawiono budowę najnowszych rozwiazań superkondensatorów dwuokładzinowych oraz Li-ion. Analiza porównawcza ich parametrów znamionowych pozwolita na przedstawienie potencjału wykorzystania $w$ trakcji elektrycznej. W kolejnym rozdziale przedstawiono wyniki badań symulacyjnych, które obrazuja wplyw różnic parametrów badanych superkondensatorów na efektywność ich wykorzystania. Następnie zamieszczono wyniki badań eksperymentalnych, majacych na celu zbadanie stałości parametrów superkondensatorów EDLC oraz LIC. Zamieszczono opis wykonywanych prób, metodykę wyznaczania szukanych parametrów oraz wykresy ilustrujace wyniki badań i obliczeń.
\end{abstract}

\section{Wstęp}

Wprowadzenie na szeroką skalę napędów impulsowych (DC i AC) w trakcji elektrycznej umożliwiło zastosowanie hamowania rekuperacyjnego i zmniejszenie zużycia energii przez tabor elektryczny. Podstawowym warunkiem wykorzystanie energii hamującego pojazdu jest obecność na odcinku zasilania innego pojazdu, który pobiera energię $\mathrm{z}$ sieci trakcyjnej. W przeciwnym wypadku energia hamowania rozpraszana jest na rezystorach hamowania.

Rozwiązaniem alternatywnym jest magazynowanie energii hamowania. Można to przeprowadzić przy pomocy zasobnika energii zlokalizowanym na samym pojeździe hamującym odzyskowo lub zasobnika (zasobników) zlokalizowanych w urządzeniach infrastruktury.

Zasobnik energii, służący do magazynowania energii z hamowania odzyskowego, powinien charakteryzować się wysokimi pramateriami technicznymi, które decydują o możliwościach technicznych i efekcie ekonomicznym:

- pojemność jednostkowa (Wh/kg);

- moc jednostkowa (W/kg) umożliwiająca całkowite naładowanie/rozładowanie w czasie do 30 sekund;

- trwałość - dopuszczalna liczba cykli ładowania/rozładowania;

- sprawność cyklu ładowania/rozładowania;

- czas samo rozładowania;

- ograniczone gabaryty z możliwością dopasowania wymiarów zasobnika do gabarytów pojazdu.

W tabeli 1. przedstawiono podstawowe parametry stosowanych magazynów energii: superkondensatorów i baterii elektrochemicznych. Najbardziej obiecujące wydają się parametry nowych, hybrydowych kondensatorów litowo-jonowych.
Tab. 1: Porównanie parametrów różnych magazynów energii

\begin{tabular}{|l|c|c|c|}
\hline $\begin{array}{l}\text { Typ elementu } \\
\text { magazynującego }\end{array}$ & $\begin{array}{c}\text { Gęstość energii } \\
(\mathrm{Wh} / \mathrm{kg})\end{array}$ & $\begin{array}{c}\text { Gęstość mocy } \\
(\mathrm{W} / \mathrm{kg})\end{array}$ & $\begin{array}{c}\text { Ilość cykli } \\
\text { życia }\end{array}$ \\
\hline $\begin{array}{l}\text { Kondensatory } \\
\text { litowo-jonowe }\end{array}$ & $10-20$ & $900-9000$ & $>100000$ \\
\hline $\begin{array}{l}\text { Kondensatory } \\
\text { EDLC }\end{array}$ & $2-8$ & $500-5000$ & $>100000$ \\
\hline $\begin{array}{l}\text { Akumulatory } \\
\text { ołowiowo- } \\
\text { kwasowe }\end{array}$ & $30-50$ & $100-200$ & $200-300$ \\
\hline $\begin{array}{l}\text { Akumulatory } \\
\text { NiMH }\end{array}$ & $60-120$ & $250-1000$ & $300-500$ \\
\hline $\begin{array}{l}\text { Akumulatory } \\
\text { cynkowo } \\
\text { bromowe }\end{array}$ & $85-90$ & $300-600$ & 2000 \\
\hline
\end{tabular}

\section{Budowa i wlaściwości superkondensatorów dwuwarstwowych i Li-ion}

Konkurencyjne cenowo w stosunku do innych magazynów energii (elektrochemicznych czy mechanicznych) są superkondensatory dwuwarstwowe EDLC (Electrochemical Double Layer Capacitor). Duża pojemność superkondensatorów pozwala na gromadzenie energii do $6 \mathrm{Wh} / \mathrm{kg}$, przy trwałości deklarowanej na 10 lat, możliwa jest realizacja rzędu 1000000 cykli ładowanie/rozładowanie. Duża moc jednostkowa umożliwia przeprowadzenie ładowania w przeciagu 30 sekund, co przyjęto za jedno $\mathrm{z}$ kryteriów zastosowania $\mathrm{W}$ pojazdach miejskich. Sprawność cyklu sięga 95\%, a czas samorozładowania - wielu miesięcy.

Aktualnie dostępne superkondensatory różnych producentów charakteryzują się podobnymi parametrami. Opierając się na danych katalogowych firm produkujących superkondensatory dla zastoso-wań trakcyjnych można określić typowe parametry dla określonych wielkości superkondensatora dwuwarstwowego EDLC.

Maksymalne pojemności dla elementów produkowanych na dużą skalę to $3000 \mathrm{~F}$ dla pojedynczego 
superkondensatora o masie około $0,5 \mathrm{~kg}$ i napięciu do $2,8 \mathrm{~V}$. Pojedyncze kondensatory muszą być łączone $\mathrm{w}$ moduły, które powinny zawierać układy sterowania, układy wyrównujące napięcie, połączenia elektryczne, konstrukcję mechaniczną. Dodatkowo moduły wyposażone są w wentylatory chłodzenia. Masa kompletnych modułów osiaga wartość około 2,2 masy samych superkondensatorów. Napięcie to jest napięciem niszczącym więc nie może być ono osiągane. Rzeczywiste maksymalne napięcie robocze może sięgać $2,5-2,6 \mathrm{~V}$. W trakcie eksploatacji pojemność maleje do około $83 \%$ a rezystancja wewnętrzna wzrasta o około $70 \%$ parametrów początkowych po $1 \mathrm{mln}$ cykli. Wartość rezystancji początkowej około $0,3 \mathrm{~m} \Omega$. Ma to istotny wpływ na sprawność procesu ładowania i rozładowania. Wzrost rezystancji powoduje wzrost strat i zwiększa nagrzewanie elementu. Spadek pojemności wymusza większy zakres napięciowy ładowania by uzyskać zbliżone energie. Należy pamiętać, że wszystkie dane katalogowe deklarowane sa dla temperatury $25^{\circ} \mathrm{C}$ a maksymalna, dopuszczalna temperatura pracy kondensatorów typu EDLC wynosi ok $40-45^{\circ} \mathrm{C}$. Wszystkie charakterystyczne parametry superkondensatora : pojemność, napięcie, rezystancja szeregowa ERS są bardzo silnie uzależnione od temperatury pracy, jak również czas życia superkondensatora, który z deklarowanych 10 lat skraca się do 4-5.

Nowe rozwiązania $\mathrm{w}$ technologii superkondensatorów są ukierunkowane na zwiększenie napięcia oraz zmniejszenie masy i objętości, a co za tym idzie zwiększenie gęstości energii i mocy. Szczególnie interesująca jest tendencja zwiększania maksymalnego napięcia komórek, przy jednoczesnym zachowaniu wysokiej pojemności, która charakteryzuje te urządzenia. Chęć poprawy istniejących technologii doprowadził do rozwoju asymetrycznych litowo-jonowych (LIC) technologii kondensatorów o imponujących właściwościach magazynowania energii.

Maksymalne napięcie LIC jest 3.8V. Ponieważ energia zmagazynowana $\mathrm{w}$ kondensatorze jest proporcjonalna do kwadratu jego napięcia na zaciskach, wzrost napięcia w stosunku do EDLC powoduje zwiększenie ilości energii. Jednocześnie elementy te charakteryzują się znacznie większymi mocami na jednostkę masy i energii na jednostkę objętości, gwarantują większe niezależność parametrów od napięcia i czasu.

Superkondensator dwuwarstwowy (EDLC) jest zbudowany $\mathrm{z}$ dwóch elektrod $\mathrm{z}$ materiału aktywnego, oddzielonych membraną (umożliwia wymianę wolnych jonów oraz chroni przed zwarciem) oraz stałego lub ciekłego elektrolitu [1]. Ze względu na mechanizm przechowywania ładunku, tak jak i rodzaj aktywnego materiału, można wyróżnić kilka typów elektrochemicznych kondensatorów. Mogą one magazynować energię za pomocą adsorpcji jonów (kondensatory elektrochemiczne $\mathrm{z}$ podwójną warstwą, EDLC) lub za pomocą szybkich powierzchniowych reakcji redox (kondensatory pseudopojemnościowe, pseudocapacitor lub redox capacitor). Kondensatory z podwójną warstwą, EDLC, są najbardziej popularnymi, a jako elektrody stosowane są materiały na bazie różnych rodzajów wegla $\mathrm{z}$ wysoce rozwinięta powierzchnią elektrod. Natomiast w przypadku kondensatorów typu redox jako materiały elektrodowe stosowane są tlenki metali przejściowych lub elektrycznie przewodzące polimery. Trzecim rodzajem są hybrydowe kondensatory litowo-jonowe. Łączą one właściwości kondensatorów i baterii poprzez połączenie elektrod: pojemnościowej lub pseudopojemnościowej z elektrodą baterii (rys.1).

Kondensatory litowo-jonowe są nowym urządzeniem do magazynowania energii elektrycznej, które łączą w sobie wysoką gęstość energii i mocy $\mathrm{w}$ porównaniu $\mathrm{z}$ kondensatorami dwuwarstwowymi EDLC. Struktura kondensatora LIC składa się $\mathrm{z}$ dwóch elektrod: dodatnia zbudowana jest $\mathrm{z}$ węgla aktywowanego podobnie jak w kondensatorach dwuwarstwowych; natomiast elektroda ujemna zbudowana jest $\mathrm{z}$ grafitu domieszkowanego jonami litu analogicznie jak w akumulatorach litowo-jonowych. (rys. 1). Technologia ta zwiększa możliwości ujemnej elektrody i zwiększa różnice potencjałów. Elektrolit jest roztworem soli litu w cieczach organicznych.
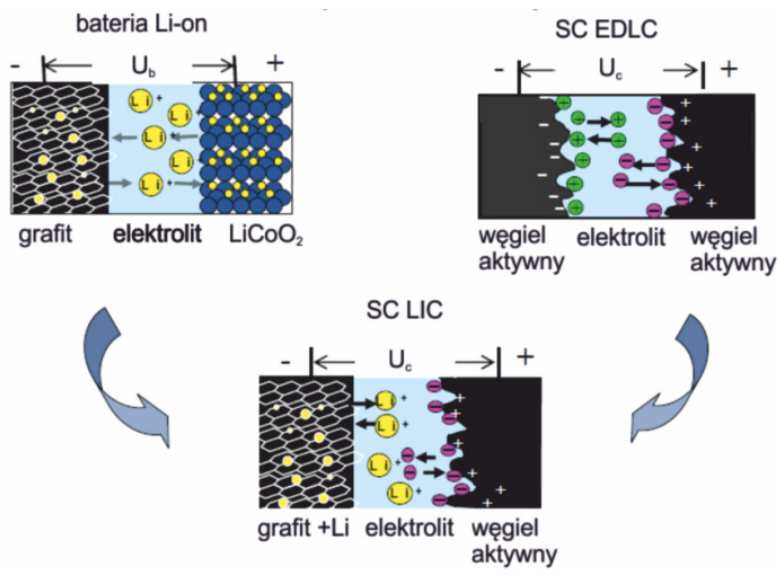

Rys. 1: Budowa kondensatora litowo-jonowego. [2]

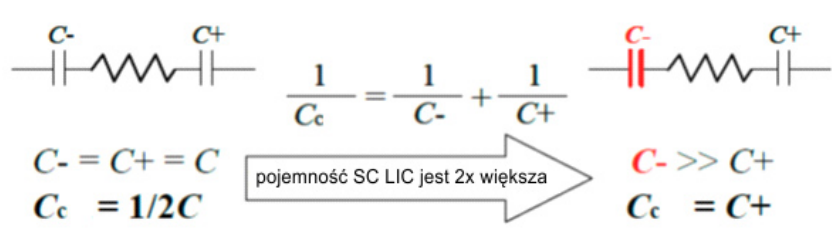

Rys. 2: Tworzenie pojemności w SC EDLC (z lewej) i LIC (z prawej). [2] 
Pojemność wypadkowa obu typu kondensatorów składa się z szeregowo połączonych pojemności utworzonych przez warstwy przyelektrodowe i pojemność utworzoną przez ujemną elektrodę akumulatora litowo-jonowego w przypadku SC LIC. Pojemność elektrody ujemnej kondensatora LIC jest znacznie większa niż pojemność jego anody, w związku z czym pojemność wypadkowa całego SC LIC może być nawet dwukrotnie większa od pojemności typowego kondensatora EDLC.
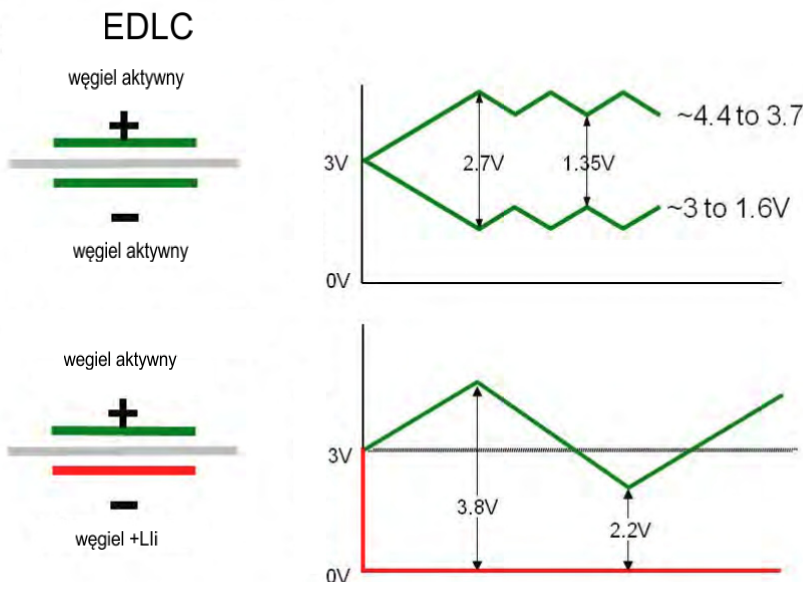

Rys.3: Napięcie wyjściowe SC EDLC (góra) i LIC (dół) [2]

Napięcie na okładkach SC jest różnicą napięć pomiędzy nimi (rys. 3). W przypadku kondensatora typu ELDC potencjał katody $\mathrm{i}$ anody zmienia się symetrycznie i maksymalne napięcie celi może przyjmować wartość $2.5 \mathrm{~V}$ do $2.7 \mathrm{~V}$. Dla kondensatorów LIC potencjał anody pozostaje stały w wyniku domieszkowania litu i maksymalna wartość napięcia celi wynosi $3.8 \mathrm{~V}$

W bateriach litowo-jonowych może dojść do egzotermicznej niekontrolowanej reakcji łańcuchowej na dodatniej elektrodzie. Następuje to w wyniku przegrzania celi i dekompozycji (rozpadu) spinelu litowego (regularnego kryształu tlenku metali i litu) i jego reakcji z elektrolitem. Dodatnia elektroda kondensatora LIC zbudowana jest $\mathrm{z}$ domieszkowanego węgla w związku z czym zjawisko to nie występuje. [5]

\section{Badania symulacyjne}

W celu określenia sprawności energetycznej zasobników różnych typów i różnych producentów przeprowadzono badania symulacyjne układu superkondensatorowego magazynu energii $\mathrm{w}$ wersji przytorowej. Zadaniem takiego rozwiązania jest magazynowanie energii hamowania wagonu tramwajowego i wspomaganie rozruchu przez stabilizacje napięcia sieci w przypadku odległej podstacji zasilającej i „miękkiej” sieci [6].

Dla modelu symulacyjnego przyjęto następujące założenia:
- magazyn energii o napięciu znamionowym 720-740V złożony jest $\mathrm{z}$ dostępnych $\mathrm{w}$ handlu modułów o zbliżonym napięciu znamionowym ok. $48 \mathrm{~V}$,

- układ zasilany jest $\mathrm{z}$ odleglej podstacji trakcyjnej, spadek napięcia na rezystancji sieci w czasie rozruchu powoduje obniżenie napięcia na pantografie poniżej napięcia znamionowego $\mathrm{U}_{\mathrm{sN}}=600 \mathrm{~V}$,

- obciążeniem jest tramwaj typu „SWING” ruszający z $75 \%$ mocy znamionowej i przyspieszeniem $1.2 \mathrm{~m} / \mathrm{s}^{2}$, w ciagu $7 \mathrm{~s}$ prąd sieci wzrasta od zera do $800 \mathrm{~A}$,

- zadaniem zasobnika jest stabilizacja napięcia sieci na poziomie $600 \mathrm{~V}$,

- jako układ energoelektroniczny dopasowujący napięcie zasobnika do napięcia sieci wybrano układ przetwornicy boost-buck w układzie $\mathrm{H}$ (pełny mostek) (rys. 4),

- przyjęto stałą wartość rezystancji sieci Rs2 i Rs 1 ,

- obliczenia wykonano w środowisku MATLAB / SIMULINK.

Zestawienie parametrów rozważanych zasobników przedstawione jest $\mathrm{w}$ tabeli 2 .

Tab. 2: Zestawienie parametrów symulowanych modułów superkondensatorów

\begin{tabular}{|c|l|c|c|c|c|c|}
\hline Firma & \multicolumn{1}{|c|}{ Model } & $\mathrm{C}[\mathrm{F}]$ & $\mathrm{U}[\mathrm{V}]$ & $\begin{array}{c}\text { ESR } \\
{[\mathrm{Ohm}]}\end{array}$ & $\mathrm{Imax}[\mathrm{A}]$ & $\begin{array}{c}\text { Masa } \\
{[\mathrm{kg}]}\end{array}$ \\
\hline Maxwell & BMOD0165P048 & 165 & 48 & 0,0063 & 1941,7 & 13,5 \\
\hline JSRMicro & MPA45G275G & 275 & 45,6 & 0,014 & 1292,8 & 5,4 \\
\hline LSMtron & $\begin{array}{l}\text { LSUM 048R6C } \\
\text { 0166F EA }\end{array}$ & 166 & 48,6 & 0,005 & 2200 & 13,2 \\
\hline
\end{tabular}

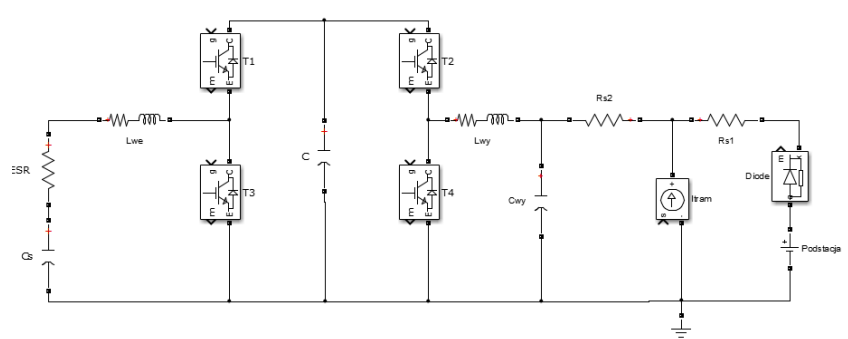

Rys. 4: Układ do obliczeń symulacyjnych

W trakcie rozruchu napięcie zasilania na odbieraku spada od napięcia $720 \mathrm{~V}$ poniżej napięcia znamionowego $600 \mathrm{~V}(1.5 \mathrm{~s})$. W tym momencie następuje załączenia tranzystora $\mathrm{T} 2$, który pracuje jako czoper obniżający napięcie (buck) i stabilizuje napięcie wyjściowe na poziomie 600V. Po rozładowaniu kondensatora poniżej napięcia sieci przekształtnik jest przełączany do pracy w trybie boost. Tranzystor T1 zostaje włączony na stałe a tranzystor T3 zaczyna kluczować i utrzymuje napięcie na poziomie $600 \mathrm{~V}$. (ok. $5 \mathrm{~s}$ ) Tak przyjęte założenia oznaczaja jednakowe warunki pracy zasobników - 
takie samo obciążenie mocą i pobranie takiej samej energii. Wyniki symulacji wykonanych w środowisku MATLAB/SIMULINK przedstawiono $w$ tabeli 3 i na rysunkach 5 i 6.

W trakcie obliczeń wyznaczono energię początkową zmagazynowana $\mathrm{W}_{\text {pocz }} \mathrm{W}$ zasobnikach, energię dostarczoną do pojazdu $\Delta \mathrm{W}$ (mierzona na odbieraku) i energię końcową $\mathrm{W}_{\text {kon }}$ zasobnika oraz sprawność względną magazynu definiowaną wzorem (1).

$$
\eta=\frac{W_{\text {kon }}}{C * W_{\text {pocx }}}
$$

gdzie: C - pojemność znamionowa zasobnika w $\mathrm{F}$

Zakończenie obliczeń następowało $\mathrm{w}$ momencie przepływu przez superkondensator prądu rozładowania. Napięcie mierzone na zaciskach pojemności składa się z napięcia na pojemności i spadku napięcia na rezystancji szeregowej $R_{E S R}$. Po zaniku przepływu prądu napięcie mierzone jest większe o spadek napięcia na rezystancji. W obliczeniach energii końcowej uwzględniony został wzrost napięcia na superkondensatorze po wyłączeniu prądu rozładowaia:

$$
W_{\text {kom }}=C_{n} \frac{\left(U_{k}+t_{k} R_{E S R}-\frac{U_{n}}{2}\right)^{2}}{2}
$$

gdzie: $n$ - indeks oznaczają wartości znamionowe, $k$ indeks wartości prądu i napięcia dla $t=7 \mathrm{~s}$

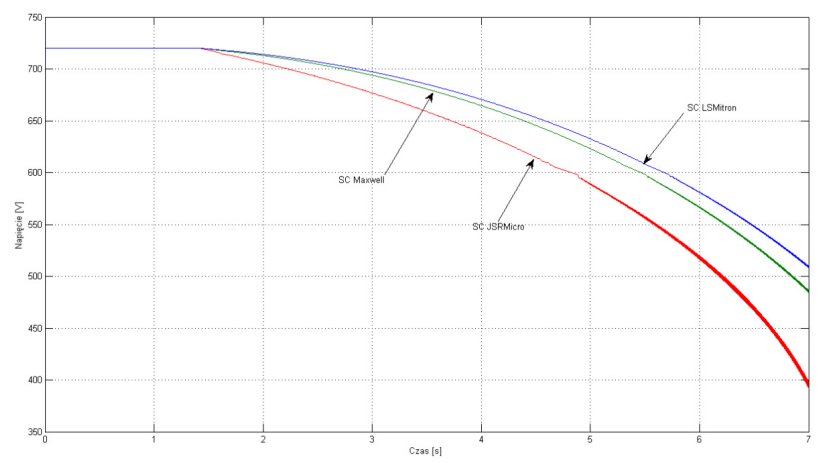

Rys. 5: Wartości średnie napięć na superkondensatorach

\section{Badania eksperymentalne}

W celu weryfikacji symulacji komputerowych i numerycznych omawianych pojemnościowych zasobników energii postanowiono przeprowadzić szereg pomiarów laboratoryjnych. Analiza otrzymanych wyników pozwoliła na identyfikacje parametrów poszczególnych zasobników oraz porównanie ich.

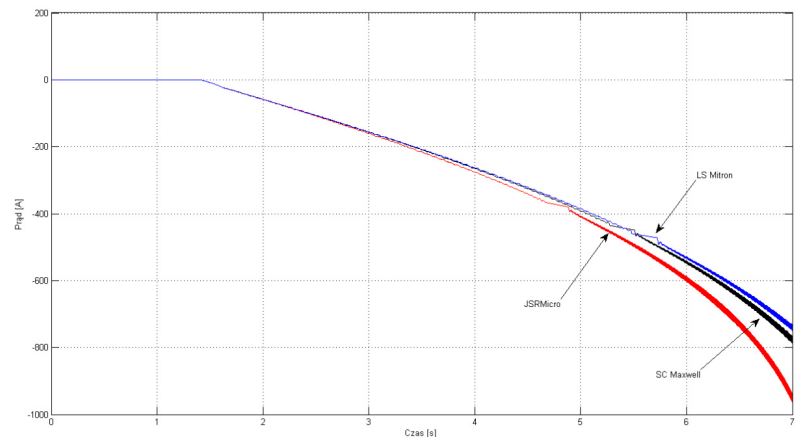

Rys. 6: Przebiegi wartości średnich prądów w superkondensatorach

Na rysunku 7 przedstawiono schemat ideowy układu pomiarowego, wraz z zaznaczonymi punktami pomiarowymi:

- MIzas - pomiar prądu zasilania układu;

- MUzas - pomiar napięcia kondensatora filtru (napięcie zasilania);

- MIsc - pomiar prądu zasobnika energii;

- MUsc - pomiar napięcia zasobnika energii.

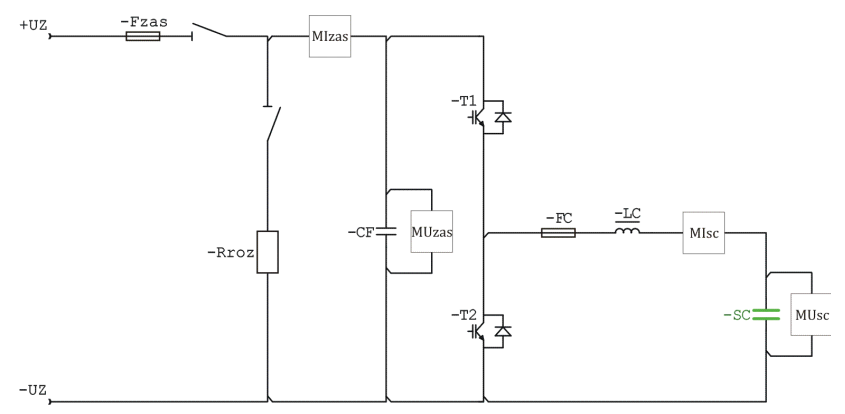

Rys. 7: Schemat ideowy przekształtnika do pomiaru parametrów zasobników energii.

Rysunek 8 ilustruje zdjęcie stanowiska laboratoryjnego, które zostało zbudowane według schematu $\mathrm{z}$ rysunku 7 .

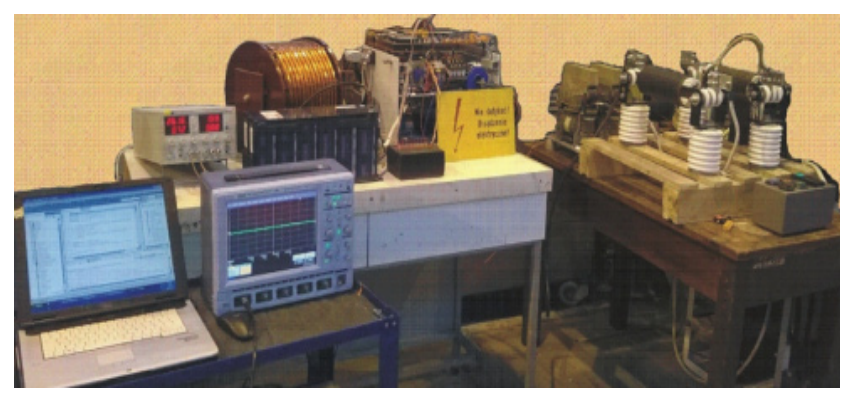

Rys. 8: Zdjęcie stanowiska do pomiarów parametrów pojemnościowych zasobników energii.

Tab. 3: Wyniki modelowania

\begin{tabular}{|l|c|c|c|c|c|c|c|c|}
\hline Producent & $\begin{array}{c}\mathrm{C} \\
{[\mathrm{F}]}\end{array}$ & $\mathrm{Ucs}[\mathrm{V}]$ & $\begin{array}{c}\mathrm{R}_{\mathrm{ESR}} \\
{[\mathrm{W}]}\end{array}$ & $\begin{array}{c}\text { Masa } \\
{[\mathrm{kg}]}\end{array}$ & $\begin{array}{c}\mathrm{W}_{\text {pocz }} \\
{[\mathrm{kWh}]}\end{array}$ & $\begin{array}{c}\Delta \mathrm{W} \\
{[\mathrm{kWh}]}\end{array}$ & $\begin{array}{c}\mathrm{W}_{\text {kon }} \\
{[\mathrm{kWh}]}\end{array}$ & $\eta$ \\
\hline Maxwell & 11,00 & 720 & 0,0945 & 202,5 & 0,198 & 0,138 & 0,060 & 0,0274 \\
\hline JSRMicro & 17,19 & 729,6 & 0,224 & 86,4 & 0,317 & 0,135 & 0,182 & 0,0334 \\
\hline LSMtron & 11,07 & 729 & 0,075 & 198 & 0,204 & 0,142 & 0,061 & 0,0272 \\
\hline
\end{tabular}


Badaniom poddano klasyczny dwuokładzinowy superkondensator firmy LSmtron typu LSUM 033 R6P 0250F EA (EDLC). Drugim typem, spośród badanych zasobników jest hybrydowy super kondensator litowo-jonowy (LIC).

W tabeli 4 zestawiono podstawowe parametry znamionowe badanych zasobników energii.

Tab. 4: Tabela z parametrami znamionowymi zasobników: LSUM 033R6P 0250F EA (EDLC) i MPA45G275H (LIC).

\begin{tabular}{|l|c|c|}
\cline { 2 - 3 } \multicolumn{1}{c|}{} & EDLC & LIC \\
\hline Pojemność & $250 \mathrm{~F}$ & $275 \mathrm{~F}$ \\
\hline Maksymalne napięcie & $\begin{array}{c}33,6 \mathrm{~V} ; \\
2,8 \mathrm{~V} / \mathrm{cela}\end{array}$ & $\begin{array}{c}45,6 \mathrm{~V} ; \\
/ 3,8 \mathrm{~V} \text { cela }\end{array}$ \\
\hline ESR(DC) & $4,8 \mathrm{~m} \Omega(\mathrm{max})$ & $12 \mathrm{~m} \Omega(\mathrm{max})$ \\
\hline $\begin{array}{l}\text { Maksymalny prąd } \\
\text { ładowania }\end{array}$ & $400 \mathrm{~A}$ & $360 \mathrm{~A}$ \\
\hline $\begin{array}{l}\text { Maksymalny prąd } \\
\text { rozładowania }\end{array}$ & $400 \mathrm{~A}$ & $360 \mathrm{~A}$ \\
\hline Waga & $9,8 \mathrm{~kg}$ & $6,4 \mathrm{~kg}$ \\
\hline Szerokość & $132 \mathrm{~mm}$ & $168,8 \mathrm{~mm}$ \\
\hline Głębokość & $414 \mathrm{~mm}$ & $127,1 \mathrm{~mm}$ \\
\hline Długość & $180,5 \mathrm{~mm}$ & $260,5 \mathrm{~mm}$ \\
\hline
\end{tabular}

$\mathrm{Na}$ rysunku 9 przedstawiono przykładowy oscylogram obrazujący przebieg prądu ładowania zasobnika EDLC oraz zmianę jego napięcia.

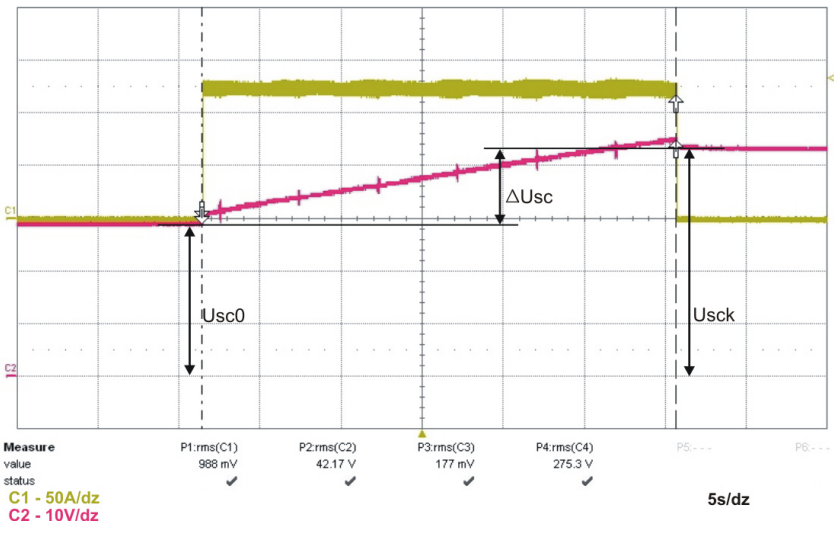

Rys. 9: Oscylogram ładowania zasobnika LIC, C1 - prąd zasobnika (Isc), C2 - Napięcie zasobnika (Usc).

Mierząc wartość początkową $\left(U_{S C O}\right)$ oraz końcową $\left(U_{S C k}\right)$ napięcia zasobnika, średni prąd $\left(I_{S C S r}\right)$ oraz czas ładowania $(\Delta t)$, na podstawie zależności (3) wyznaczono pojemność zasobników.

$$
C=\frac{\text { Iscsr }-\Delta t}{\text { Usck Usc0 }}
$$

Wyznaczając z zależności (5) energię pobraną przez zasobnik w trakcie ładowania $\left(E_{i n S C}\right)$, oraz energię zgromadzoną $\left(E_{S C}\right) \quad \mathrm{z}$ zależności (6), otrzymano sprawność zasobnika (4).

$$
\eta s c=\frac{E s c}{\text { Einsc }} \cdot 100
$$

$$
\begin{aligned}
& \text { Einsc }=U_{S C s r} * I_{S C s r} * \Delta t \\
& \text { Esc }=\frac{\left(\mathrm{Usck}^{2}-\mathrm{Usc0}^{2}\right) \cdot \mathrm{c}}{\mathbf{2}}
\end{aligned}
$$

\subsection{Zmienność parametrów $w$ funkcji napięcia}

W wielu publikacjach dostrzeżono zależność parametrów zasobników energii od występującego na nim napięcia [3] [4]. Zjawisko to zostało opisane zarówno dla klasycznych superkondensatorów (EDLC) jak i dla hybrydowych superkondensatorów lito-jonowych (LIC). Pojemnościowe zasobniki energii pracują w szerokim zakresie napięcia, dlatego wpływ napięcia na ich parametry może mieć znaczące znaczenie dla efektywności ich zastosowania.

Wielkością zadaną dla poszczególnych punktów pomiarowych był przyrost napięcia zasobnika $\left(\Delta U_{S C}\right)$. Wykonano dwie serie pomiarów zarówno dla zasobnika LIC jak i EDLC. W pierwszej serii wielkością stałą było początkowe napięcie ładowania $\left(U_{S C O}=c o n s t\right)$, natomiast kolejno zwiększano poziom końcowego napięcia procesu $\left(U_{S C K}\right)$. W kolejnej serii pomiarowej założono stałą wartość napięcia końcowego ładowania $\left(U_{S C k}=\right.$ const $)$, natomiast kolejno zmieniano wartość napięcia Usc0. Pomiary wykonano dla obydwu rodzajów zasobników ładując je prądem Isc $=100 \mathrm{~A}$.

Poniżej przedstawiono wyniki pomiarów dla serii pomiarowej $\mathrm{z}$ założeniem: $U_{S C O}=$ const. $\mathrm{Na}$ rysunku 10a przedstawiono porównanie zmienności pojemności zasobników, natomiast rysunek 10b przedstawia zestawienie charakterystyk ich sprawności dla wyżej opisanej serii pomiarowej.

a)

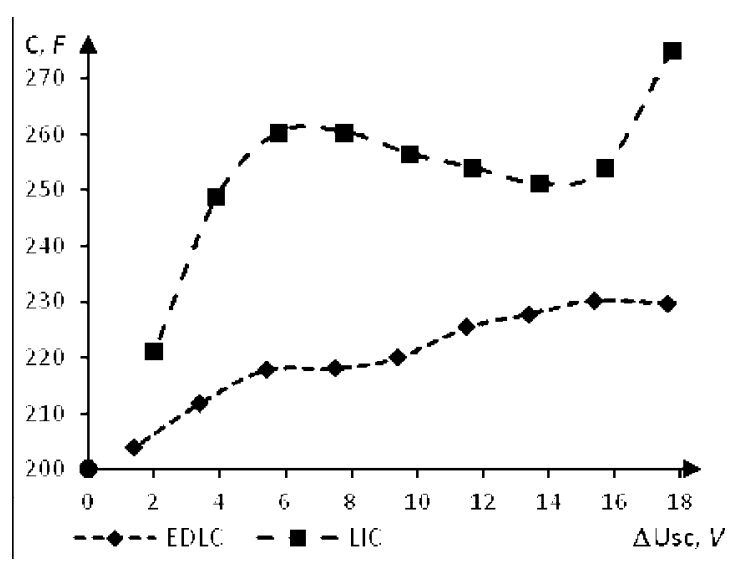

b)

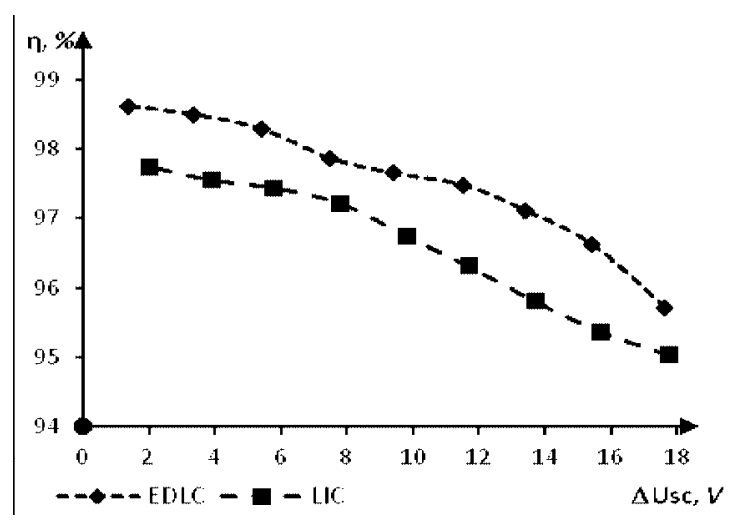


Rys. 10: Wykresy zmienności pojemności (a), sprawności (b) i strat (c) badanych zasobników energii, dla napięcia początkowego: Usc $0=$ const.

Analizując powyższe wykresy można zauważyć dużą zależność wartości parametrów elektrycznych badanych zasobników od występującego na nich napięcia. Dla zasobnika EDLC różnica pomiędzy maksymalną (230F) a minimalną (204F) osiagniętą pojemnością wynosi $24 \mathrm{~F}$, co stanowi $10,4 \%$ jego znamionowej pojemności (250F). Dla zasobnika LIC maksymalna zmierzona pojemność wyniosła $275 \mathrm{~F}$, a minimalna $221 \mathrm{~F}$, zatem zmienność pojemności, w odniesieniu do znamionowej pojemności zasobnika wynosi $19,6 \%$. Chociaż otrzymane charakterystyki są nieliniowe, można założyć, że pojemność obydwu zasobników rośnie wraz z wzrostem jego napięcia.

W odróżnieniu do pojemności, sprawności badanych zasobnikach są, mniej więcej, funkcją liniową napięcia, stale opadającą. Największa wyznaczona w tej serii pomiarowej sprawność zasobnika EDLC wyniosła $\eta_{M A X}=98,62 \%$, a najniższa - $\eta_{M I N}=95,72 \%$. Dla zasobnika LIC sprawność zawierała się $\mathrm{w}$ granicach: $\eta_{M A X}=97,74 \%, \eta_{M I N}$ $=95,04 \%$.

$\mathrm{Na}$ poniższych wykresach $11 \mathrm{a}$ i $11 \mathrm{~b}$ przedstawiono zależności zmienności pojemności i sprawności badanych zasobników energii $\mathrm{w}$ funkcji ich napięcia, dla serii pomiarowej z założeniem $U_{S C k}$ = const.

a)

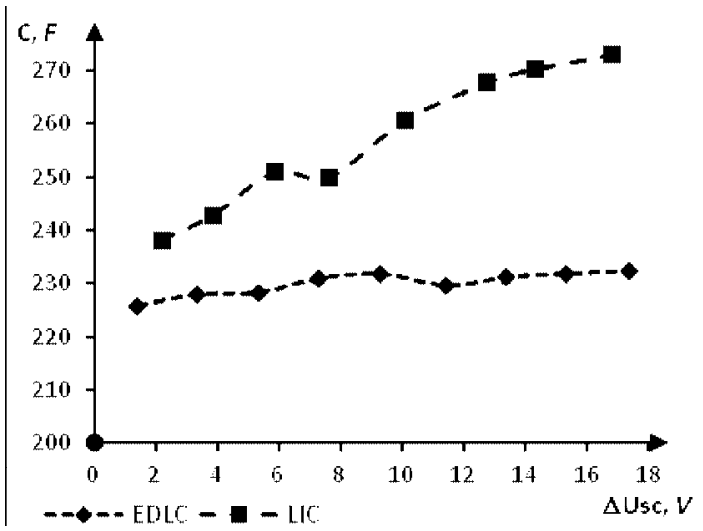

b)

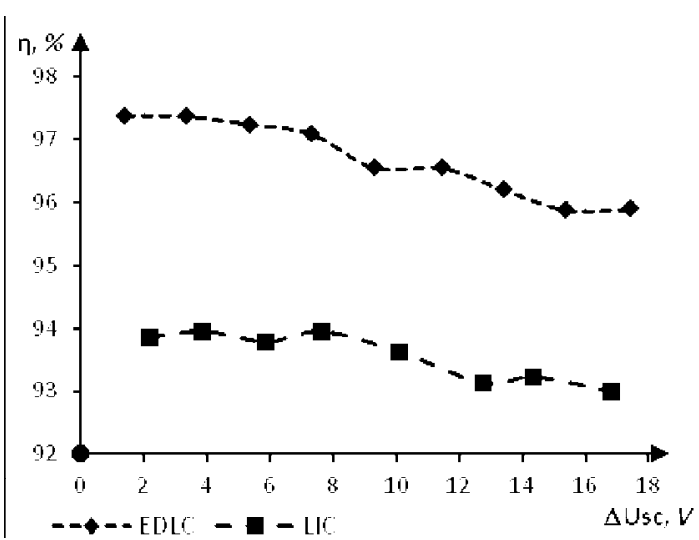

Podobnie jak dla poprzedniej serii pomiarów $\left(U_{S C O}=\right.$ const $)$, analizując wykresy dla pomiarów z założeniem $U_{S C k}=$ const., można zauważyć zależność wartości parametrów elektrycznych badanych zasobników od występującego na nich napięcia, jednakże ich zmienność niekiedy ma inną wartość, a charakterystyki różne kształty. Dla zasobnika EDLC różnica pomiędzy maksymalną (232F) a minimalną (226F) osiagniętą pojemnością wynosi $24 \mathrm{~F}$, co stanowi $2,4 \%$ jego znamionowej pojemności $(250 \mathrm{~F})$. Dla zasobnika LIC maksymalna zmierzona pojemność wyniosła $273 \mathrm{~F}$, a minimalna 238F, zatem zmienność pojemności, w odniesieniu do znamionowej pojemności zasobnika wynosi 12,7\%.

Otrzymane wykresy $\mathrm{z}$ rysunku $11 \mathrm{~b} \quad \mathrm{z}$ powodzeniem można aproksymować do linii prostych. Sprawność obydwu zasobników była największa przy małych wartościach napięć (dla EDLC: $\eta_{M A X}=97,38 \%$, dla LIC: $\eta_{M A X}=93,96 \%$ i malała wraz z wzrostem napięcia do wartości $\eta_{M I N}=95,88 \%$ dla EDLC oraz $\eta_{M I N}=92,99 \%$ dla LIC.

\subsection{Zmienność parametrów $w$ funkcji prądu}

Mając na uwadze otrzymane $\mathrm{w}$ podrozdziale 4.3 wyniki pomiarów i obliczeń, postanowiono zbadać wpływ wartości prądu ładowania zasobnika na charakter jego parametrów. W tym celu wykonano pomiary, w których ładowano zasobniki różnymi wartościami prądu.

Na podstawie wykonanych pomiarów przedstawiono charakterystyki wybranych wielkości: zmienności pojemności (rys. 12a) oraz sprawności (rys. 12b) badanych zasobników w funkcji prądu ładowania I IS.

Zgodnie $\mathrm{z}$ przypuszczeniami, po analizie przedstawionych wykresów, można stwierdzić zależność pojemności i sprawności badanych zasobników od prądu ładowania. Dla zasobnika EDLC różnica pomiędzy maksymalną $(236 \mathrm{~F})$ a minimalną $(227 \mathrm{~F})$ osiagniętą pojemnością wynosi 9F, co stanowi 3,6\% jego znamionowej pojemności (250F). Dla zasobnika LIC maksymalna zmierzona pojemność wyniosła 262F, a minimalna 249F, zatem zmienność pojemności, w odniesieniu do znamionowej pojemności zasobnika wynosi $4,7 \%$. Chociaż otrzymane charakterystyki są nieliniowe, można założyć, że pojemność obydwu zasobników maleje wraz z wzrostem prądu ładowania.

Sprawność obydwu zasobników malała wraz z zwiększaniem wartości prądu ładowania od $\eta_{M A X}=97,3 \%$ dla EDLC i $\eta_{M A X}=95,9 \%$ dla LIC, do $\eta_{M I N}=95,3 \%$ dla EDLC oraz $\eta_{M I N}=94,17 \%$ dla LIC. 
a)

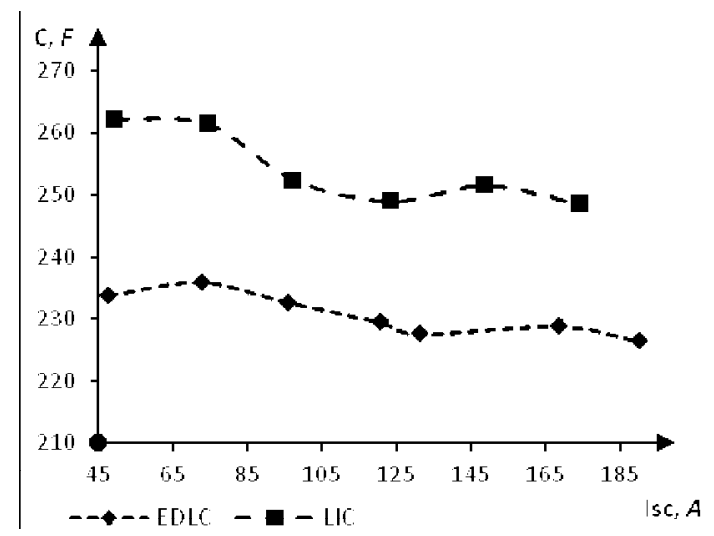

b)

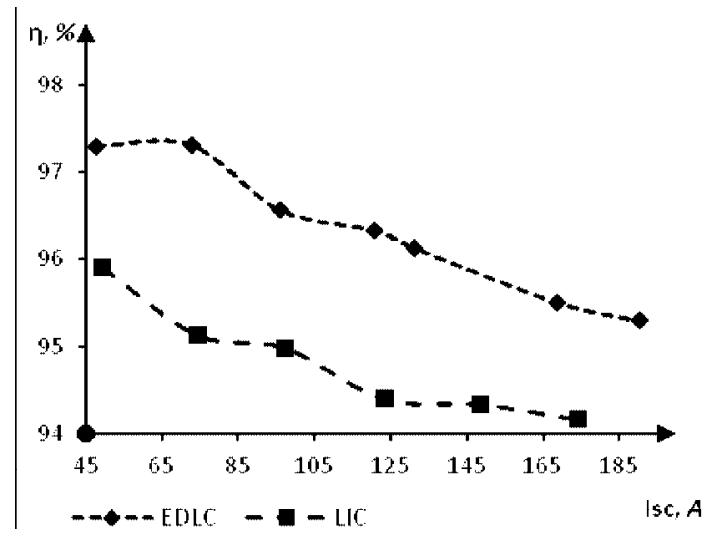

Rys. 12: Wykresy zmienności pojemności (a) i sprawności (b) w funkcji prądu zasobnika.

\section{Wnioski}

Superkondensatorowe ogniwa LIC charakteryzują się znacznie większym napięciem znamionowym w stosunku do ogniw EDLC, przy zbliżonych wartościach pojemności. Powyższy fakt skutkuje znacznie większą możliwością magazynowania energii elektrycznej przez zasobniki LIC, a tym samym korzystniejszymi współczynnikami pojemności i mocy jednostkowej. Okupione jest to jednak większym parametrem ESR, co skutkuje szeregiem negatywnych zjawisk.
Badania symulacyjne wykazały szybsze rozładowywanie zasobników z zwiększonym parametrem ESR, co skutkuje wzrostem wartości prądu rozładowania. Z kolei badania eksperymentalne potwierdziły mniejszą sprawność zasobnika LIC.

Obserwacje parametrów elektrycznych badanych zasobników energii wykazały zależność zarówno ich pojemności jak i sprawności w funkcji napięcia $\mathrm{i}$ prądu. Opisane zjawisko występuje dla obydwu typów badanych zasobników: EDLC i LIC.

\section{Bibliografia}

[1] Conway BE. „Electrochemical supercapacitors: scientific, fundamentals and technological applications." New York: Plenum; 1999.

[2] J. Banas and M. Peterson, "Advances in ULTIMO TM Lithium Ion Capacitor (LIC) Technology," in NCCAVS "Technology for Clean Energy," 2012, p. 36.

[3] S. Barcellona, F. Ciccarelli, D. Iannuzzi, L, Piegari, „Modeling and Parameter Identification of LithiumIon Capacitor Modules", IEEE Transactions On Sustainable Energy, Vol. 5, No. 3, July 2014

[4] F. Bensmainea,b, S. Tnania, G. Champenoisa, E. Mouni, ,Modeling and Parameter Identifiation of Supercapacitors Using a Bidirectional DC-AC Converter", Industrial Electronics Society, IECON 2013 - 39th Annual Conference of the IEEE

[5] JSR Micro, “JM Energy's Lithium Ion Capacitor: The Hybrid Energy Storage Advantage," 2009.

[6] M. Lewandowski, M. Orzyłowski, E. Bramson, „Badania zastosowania super-kondesatorowego zasobnika energii ulokowanego na końcu linii tramwajowej", Logistyka, 3/2015 